\title{
KIN-WORK IN A TIME OF JIHAD: Sustaining Bonds of Filiation and Care for Tunisian Foreign Combatants
}

\author{
ALYSSA MILLER \\ Duke University \\ (D) http: / / orcid.org/0000-0002-2100-8517
}

The scene begins in a domestic interior, where a finely crafted desk stands beneath an open window. Displayed prominently on the desk is a family portrait featuring three generations of respectable folk gathered in downtown Tunis. Daylight streams in through a gauzy curtain that flutters gently in the breeze. Suddenly, a gust of wind from the open window sows chaos into this placid scene. The family portrait pitches forward precariously — but the moment passes quickly. A woman now moves into view; she fastens the window shut and steadies the photo, brushing away a bit of dust from the frame before exiting the room. Yet the wind outside proves insistent. As dramatic music plays, the window bursts back open and the wind, rifling recklessly through the pages of a leather-bound Qur'an, tips the portrait over and sends it smashing to the ground. While the camera pans over shattered glass, a voice-over cautions: "We don't realize the danger until it's already too late. Just like the terrorism here in our country, which draws closer every day. Terrorism doesn't only exist abroad. One day, it may enter our houses." Zooming in again on the photograph, we see that the image has changed. Where the loving family once gathered, there is a single child, orphaned and forlorn. In the background, Tunis resembles a war zone, reduced 
to smoldering ruins. The scene then cuts to black, revealing a message in stark white text: "Terrorism is not who we are."

This public service announcement, broadcast to Tunisian television audiences in 2014, assigns the family a critical security role in Tunisia's domestic war on terror. As the nation's basic social unit, the family constitutes the first line of defense against the threat of radical Islam. It is up to each family to protect the nation by surveilling their kin, ensuring that no one is seduced by dangerous outside ideas. Yet there is something uncanny about the outside threat, represented here as a force of nature that slips surreptitiously into domestic life and begins to wreak havoc. Despite the assertion that "terrorism is not who we are," the very need for such a publicity campaign belies this categorical assurance.

What happens when a Tunisian family confronts the knowledge that their child has become a soldier for transnational jihad? After the 2011 prodemocracy uprising in Syria transmogrified into regional war, between three and six thousand Tunisians traveled to the eastern Mediterranean to join jihadi militias, making Tunisia the largest exporter per capita of foreign combatants to the conflict. While the state and its televisual representations have excised the jihadi from the Tunisian national family, such a clean break is unavailable to the kin whom foreign combatants leave behind. In the mainstream public imaginary, the figure of the jihadi violates the symbolic kinship of nation, religion, and humanity, quitting national soil to engage in fratricidal violence against fellow Muslims. Kin to combatants thus become paradoxical victims of jihad, suffering the agonizing loss of a son while also falling under suspicion for failing to prevent his religious deviancy. ${ }^{2}$ Like a phantom limb, foreign combatants exert a powerful affective hold on their families, leaving a painful complex of longing and shame in place of their presence.

Anthropologists have long viewed kinship as more than mere biological descent, documenting the diverse ways in which kin are made beyond heterosexual reproduction (Strathern 1992; Franklin and McKinnon 2001; Carsten 2004; Haraway 2016). Michael Lambek (2013) proposes a performative model, whereby kinship is enacted through intentional acts that carry ethical consequences, such as calling someone by a kin-term or recognizing the paternity of a child. In this article, I build on Lambek's insight to examine the politics of kin-work as performed by the families of Tunisian combatants lost at war in the eastern Mediterranean. Kinship relations are characterized by "diffuse, enduring solidarity" (Schneider 1980, 116), feelings that are neither natural nor given, but require the steady work of time, attention, and care (see Weston 1991). Following Micaela di Leonardo (1987), I use kin-work to refer to a form of affective labor that 
sustains relations of care for sons engaged in jihad and seeks to pressure a resistant state into facilitating their repatriation. My discussion is based on relationships with families of foreign combatants cultivated during fieldwork in Tunisia from 2014 to 2016, as well as participant-observation of their advocacy work with a Tunisian NGO, the Rescue Association for Tunisians Trapped Abroad (RATTA). ${ }^{3}$

In a hostile public sphere where the jihadi denotes a monstrous form of life (Puar 2007), any political advocacy for foreign combatants requires first recovering their humanity. In its political register, kin-work comprises public acts that refold the combatant into the family's relational bonds, making visible how the loss of kin leaves families vulnerable to catastrophe. By mobilizing sentiments of loss, families make moral claims for state assistance (Chatterjee 2004), despite their sons' embrace of a jihad project that existentially threatens the nation. Kinwork, however, cannot be fully circumscribed by any political instrumentality. The work of caring for kin caught up in transnational circuits of violence thrusts families into a liminal zone between absence and presence, life and death, intimacy and strangeness. The analysis of kin-work must therefore attend to the ways that transnational violence reconfigures kinship itself, as families manage the ontological uncertainty that absence introduces into their intimate lives (Stevenson 2014).

\section{TUNISIANITÉ AND THE UNRULY SUBJECT}

In her writings on the ethics of mourning under the global war on terror, Judith Butler (2004, 2009) describes how representational regimes govern how lives are perceived as human. For Butler (2009), the destruction of civilizational enemies is enabled by "frames of war" that designate certain lives as worthy of being lived, whereas others do not register as lives at all. While the geographical distances inherent to wars of global scale facilitate the uneven distribution of security that Butler describes, markers of difference, such as race, religion, or class, can structure biopolitical hierarchies among more localized populations.

The public service announcement with which this essay began enacts such a biopolitical framing through its representation of the Tunisian family who merits rescue from terror. Visual cues identify them as the embodiment of a hegemonic national identity known as Tunisianité, which is religiously tolerant, culturally Francophile, educated, middle-class, and moderate in its expression of Islam (Zemni 2016). Engendered by modernizing reforms promulgated by the country's first president Habib Bourguiba, the nuclear family functioned as a key technology for crafting Tunisianité, used to subjugate extranational allegiances of tribe and religion to state power (Charrad 2001). These qualities underwrite a narrative of 
Tunisia's liberal-secular exceptionalism among Arab nations, which has been central to both its postcolonial identity and its national security rationale. During fifty-five years of authoritarian rule, President Bourguiba and his successor Zine el-Abidine Ben Ali repeatedly invoked the need to preserve Tunisia's unique moderation to justify state violence, eradicating political Islam and brutally disciplining all but the most benign and state-sanctioned forms of religious expression (Hibou 2011).

The 2011 revolution radically decentered the hegemony of Tunisianite by foregrounding marginal actors as the primary agents of history (Bayat 2015). Unruly subjects - particularly unemployed youth - emerged as national heroes for confronting the lethal force of police in their neighborhoods during the uprising (Allal 2011; Aloui 2012). Once mobilized, Tunisian youth did not return to their houses following Ben Ali's ouster, but engaged in a flurry of civic, cultural, and charitable projects, reflecting a desire to protect their revolution and shape the democracy to come. Not all of these projects have been liberal in nature (Marks 2013). During a period of interim governance (2011-2013) overseen by the Islamist party Ennahda, questions of religious identity sharply polarized the populace into secular and Islamist camps (Zeghal 2013). ${ }^{4}$ By their own account, Ennahda mismanaged an increasingly militant wave of Salafi violence by approaching it with paternalistic leniency (International Crisis Group 2013). Sympathizing with Salafi activists as “our sons," Ennahda's use of kinship idioms signaled their desire to reorient the national family toward a transnational community of believers (umma). Yet this brief experiment in Islamist governance sharply came to an end in 2013 with the assassination of two leftist politicians by members of the Salafi group Anșār al-Sharı̄'a, sparking protests that forced Ennahda into a negotiated step-down from power. The 2014 election of the secularist president Beji Caid Essebsi reterritorialized Tunisia into the ideological coordinates of Tunisianité under an ascendant war on terror. Even Ennahda moved to distance itself from transnational Islamist currents as dangerous and inauthentic imports into the $\mathrm{Tu}$ nisian national context (Cavatorta and Merone 2015).

Ambient fears provoked by postrevolutionary upheavals in religious identity and the nation-state form have hardened mainstream Tunisian opinions against legal protections for terrorism suspects. Proposed reforms to Tunisia's 2003 Counterterrorism Law, which would bring this artifact of dictatorship into conformity with international human rights norms, became an incitement to discourse that excised terrorists from the category of the human. Statements such as "we cannot afford to respect human rights for terrorists" became relatively banal during 
my fieldwork. Or, on the fate of Tunisian militants fighting in Syria: "Just let them die there. They are no longer welcome in Tunisia.” My purpose in raising the question of humanity for foreign combatants is not to argue simplistically that “all lives matter.” However, as Paul Amar (2011, 40) observes, the terrorist and jihadi are figures generated by security discourses as "problems to be solved"; they are "not actually recognizable as social formations and cannot speak on their own terms as autonomous subjects." It is therefore critical to ask what Tunisian youth believe themselves to be doing when they embark on the ethical project of jihad (see Devji 2008). This is a different task than identifying any ideology motivating jihadism in Tunisia, since it demands that we apprehend the precariousness of these young men's existence from within their lifeworlds (Butler 2004).

In her work on state recognition for indigenous land claims in Australia, Elizabeth Povinelli $(2002,234)$ remarks that "some people are foreclosed from entering the human realm in order that a nation can be made more human(e).” While the notion of Tunisianité establishes religious tolerance as an innate quality of the Tunisian personality, certain religious subjects must nevertheless be eliminated to uphold the nation's moderate cultural character (Handler 1988). In deciding the boundary of who will and will not belong to the national family, the state remains the ultimate arbiter. Given that citizenship in postauthoritarian Tunisia remains weak (Jayal 2013), the violence of such exclusion will likely be enacted not through the revocation of citizenship, but through indifference and "benign neglect" (Herzfeld 1993, 33). When the state responds by doing nothing, Tunisian combatants are exposed to death as part of the normal course of war.

The family, however, is more than just a metaphor for the body politic, held together by nationalist ideology. While the modern nuclear family may largely be an effect of kinship's partial subsumption by the state, kinship itself has an excessive quality that "cannot be rationalized . . . [or] reduced to an effect of biopolitics" (Lambek 2013, 256). Perhaps the most powerful name for the excess ascribed to kinship is love, a word that "indicates the affective site where choice and compulsion are blurred" (Povinelli 2002, 229). Thus, even if the foreign combatant has chosen another loyalty over the nation, those kin-members bonded to him by love cannot simply choose to abandon him. For them, the loss of a son is tantamount to the destruction of the family, both as a genealogical principle and as a nexus of intimate attachment. Tunisia's postrevolutionary constitution, adopted in January 2014, maintains that "the family is the nucleus of society and the state shall protect it" (Tunisian Const. art. VII). This pastoral commitment offers a potential counterweight to security imperatives that would abandon for- 
eign combatants outside of citizenship's protective scope. Kinship therefore opens up a strategic breach from "the other side of legality" (Chatterjee 2004, 56), where moral claims for foreign combatants can be made on behalf of their families.

\section{PERFORMING KIN BONDS IN PUBLIC}

On the last Sunday of November in 2014, RATTA staged a demonstration outside the Municipal Theater in Tunis. Having traveled to the capital from all over the country to attend the event, families assembled on the theater stairs bearing photographs of their loved ones - mostly official portraits of young men ensconced in wooden or gilt frames. A banner spanning the scene communicated a simple message to passersby: Hissū binā. Feel for us.

Polls would open the following morning for Tunisia's first democratic presidential election, but the eve of the election had been declared a day of mandatory silence on the campaign trail. Members of RATTA seized on this opportunity to raise awareness about the plight of Tunisian citizens said to be "trapped" in the eastern Mediterranean. In early 2012, as the Assad regime brutally cracked down on Arab Spring protesters rather than yield to democratic reform, the Tunisian interim president Moncef Marzouki had cut diplomatic ties with Syria in solidarity with the embattled revolution. As a consequence of this principled stance, Tunisians no longer had recourse to state assistance in locating kin who went missing in Syria. Under the Marzouki presidency, which drew its own legitimacy from revolution, state officials met RATTA's entreaties to end the diplomatic ban with either silence or derision. The Sunday protesters implored the electoral victor to restore diplomatic relations with Syria as the first step toward reuniting their families.

But who were the Tunisians trapped abroad, and how had they come to be stranded in war-torn Syria? Although Muhammad Iqbal Ben Rejeb, RATTA's founder and director, maintained that many had been haplessly ensnared, having moved to Syria for work or marriage prior to the Arab Spring, a cursory survey of the rally revealed that they were mostly young men whom the law referred to as "foreign combatants." If these missing men were truly trapped, their willing departure for Syria to wage jihad made it difficult to construe them as victims who now merited state assistance. Pedestrians who paused to gawk at the demonstration from the sidelines used less delicate terminology: they called these young men terrorists (īrhābīn), and some loudly and bitterly berated RATTA for what they considered traitorous support for them while Tunisian soldiers lost their lives in the war on terror. ${ }^{5}$ 
Due to the importance of the upcoming election as a milestone in Tunisia's democratic transition, the international press presence at the rally was thick. While some families lingered on the stairs, cradling picture frames in their laps or silently holding them aloft, others sought out the journalists directly, tearfully addressing the television cameras. Milling among the demonstrators, I observed the following exchange between an Arab journalist and a mother from Medenine Province.

Journalist: Tomorrow, elections will be held in Tunisia. A lot of people are looking for work. As a mother, what are you looking for?

Mother: My message for the new government is simple: bring back our sons. Beyond that, I ask for nothing, not for work or anything else. I don't have any blood left in my veins, I don't have any love left except for my son. I swear to God he was the only one in everything. Bring back my son, even if there is no work, at least let him sleep. Even if he is sick, or handicapped, or anything else is wrong with him. The important thing is my son, that's all, that he listens to me and to God. If they did anything wrong, forgive them. They did something wrong, but for our sake, forgive them.

This mother did not frame her appeal to state assistance as a legal-juridical right to due process on national soil, but addressed a higher moral reason rooted in the kinship relation. Her message expresses the violence that jihad enacts on the family, as a misguided adventure that disfigures the family's nuclear form. As a metaphor for biological kinship, her reference to blood evokes the substantive bond that ties a mother to her son, as well as the expenditures of pain and exhaustion provoked when their natural connection is severed (Schneider 1980). Yet blood symbolism also circulates in nationalist discourse to evoke the moral sense of the nation as family (Herzfeld 1993), begging the question: who has a greater claim, kinship or the nation? While nation-states use a variety of techniques to invest the family with national sentiments, here the specter of a son's loss creates a direct conflict between national and kin obligations (Mankekar 1999; Abu-Lughod 2005). The mother's appeal therefore takes the form of a bargain: in exchange for return, she renounces aspirational life for her son beyond the home. Emptied now of fugitive desires, she portrays her household as the ideal unit of governmentality, asking the nation-as-family to "forgive" transgressions without recourse to a court of law. The state should return her son not because 
he is blameless, but because acting otherwise would abandon his mother to immeasurable pain.

\section{THE EFFICACY OF FAMILIAL SENTIMENTS}

Muhammad Iqbal is a former boxer. His hands, which lay politely folded in his lap during our interview in a Tunis hotel lobby, had dark callouses at the knuckles, permanent traces of impacts in the ring. "In boxing," he tells me, "you either knock out your opponent, or you get knocked out. You hit, you hit, and you hit again. Only cowards throw in the towel." As the director of RATTA, Iqbal has put forward an advocacy strategy for families rooted in persistence and a belief in the power of emotional spectacle. He founded RATTA in 2013 after his brother, Aziz, ran away from home to join Jubhat al-Nuṣra in Syria. Incredibly, Iqbal managed to secure safe passage for Aziz back to Tunisia, and this success has made him a figure of hope for the other RATTA families.

Aziz's disappearance proved particularly alarming because he has a disability that requires him to use a wheelchair. A second-year university student majoring in computer science, Aziz told his family over the phone that he was recruited to wage "computer science jihad" (jihad informatique) because he was a genius in the field. Iqbal did not find this narrative credible: "My brother is not a computer genius - he's a student who hasn't completed his studies.” Given Aziz's physical limitations, Iqbal was filled with a dreadful premonition that his brother would be sent on a suicide mission. At the time of Aziz's disappearance, their father's advanced age and diabetes had made Iqbal the man of the house. His devastated mother therefore looked to him to recover her youngest child: "When Aziz left home, I watched my mother enter a state of mourning. It was as if she were begging me for help. I had never experienced this before in my life.”

This instance of transferable affect became a foundational moment for Iqbal, grounding his faith in the power of kin sentiments to stir hearts into action. Unlike humanitarian strategies of immediation where the body is used to express a universal humanity for the suffering subject (Malkki 1996; Allen 2009), Iqbal's work draws its emotive power from local understandings of gendered family relations. In the patriarchal Muslim family, the relationship between mothers and sons is particularly affectionate, especially in working-class environments where women have limited access to public space (White 2004). ${ }^{6}$ Iqbal therefore prefers to showcase maternal sentiment, foregrounding the mother as the archetypical figure of kin-suffering at demonstrations. "When a mother loses her son, the other family members feel ashamed. The husband can always go to a café to get out of 
the house, but the mother cannot. When a mother no longer wants to be involved in the world, it moves everyone around her."

After an ill-conceived trip to Libya to intercept Aziz in Tripoli, Iqbal resolved to take the scandal of his brother's recruitment story to the media. Thanks to an atmosphere of moral panic over youth conversions to violent extremism, he quickly secured an invitation to appear on a popular political talk show. During his television appearance, Iqbal displayed images of Aziz and denounced Jubhat al-Nușra for exploiting his disability. Invoking the pathos of his mother's pain, Iqbal began to cry openly, and the profusion of tears from this large, masculine persona elicited a powerful sympathy from the audience. Contemporary Tunisian television viewers have developed a taste for such melodramatic scenes, due to the popularity of reality programming focused on family crisis. Acting as a masculine conduit for maternal despair, Iqbal's tears achieved their evocative force by simultaneously transgressing and reinforcing normative expectations of gender performance.

Shortly after his television appearance, which was broadcast in Syria via satellite, Jubhat al-Nuṣra contacted Iqbal through an intermediary. They claimed that they could longer adequately care for Aziz and sought to repatriate him. Although Iqbal places little stock in Jubhat al-Nuṣra's capacity for concern, he believes that his media appearance forced a change of fortune by damaging the militia's reputation among potential recruits: "Seeing a handicapped person, that makes you feel bad. It gives a bad image to their revolution.” He surmises, moreover, that the dissemination of Aziz's image liquidated his use-value as a soldier for the militia. Likening Jubhat al-Nușra to the Mafia, Iqbal remarked that Aziz had become a "card already played" (waraqa maḥrūqa), a former asset now rendered a liability for the organization.

Based on this experience, Iqbal believes that mobilizing emotion is the only way to pressure the state into honoring its constitutional obligation to protect the family. While the transitional government may resist normalizing relations with the Assad regime, the Tunisian public's compassion could still be mobilized to induce a policy change. In the meantime, RATTA functions as a surrogate kinship structure for the families of foreign combatants. As Iqbal explained, given that "each of [them] has either lost someone or has someone in prison," RATTA members are bonded through a common pain that is difficult for outsiders to understand. During public appearances, Iqbal always wears a T-shirt emblazoned with his personal telephone number, extending a lifeline to families longing to exit the isolating shame of their own domestic tragedies. 
Its members united in love for sons whose participation in jihad categorizes them as enemies of the state, RATTA requires an alternative principle to constitute itself as a moral community worthy of the state's pastoral care (Chatterjee 2004). Collective suffering provides such a principle. To render that pain legible to a national public, however, families are solicited to perform according to normative scripts that shore up the state's position as guarantor of their wellbeing and protection (Taylor 1997). For those who privately blame the state itself for their sons' disappearance, such performances inevitably enact their own forms of epistemic violence.

\section{LINES OF FLIGHT FROM FILIAL PIETY}

After the revolution obliterated the state's monopoly on religion, Tunisia's formerly outlawed Salafi movement experienced a remarkable efflorescence. Salafism is a transnational counterpublic that seeks to recover an original, authentic Islam through the methodical cultivation of "new identities and alternative norms" (Wiktorowicz 2005, 211). Far from a monolith, the Salafi movement contains significant ideological fractures and diversity, many of which are reproduced in the Tunisian Salafi scene (Meijer 2009). Scholars disagree on whether contemporary ISIS-style jihadism truly constitutes a form of Salafism, due to the former's comparatively shallow textual engagement and apparent disinterest in orthopraxy. Nevertheless, they share an overlapping matrix of ideological commitments and can therefore coexist within the same spaces and communities (Roy 2017). When jihadism began to take root in certain mosques and neighborhood gathering places in Tunisia, many pious-minded parents were unaware of the risks these emergent publics might pose for their children (Ben Ammar 2014). The precipitous nature of their sons' conversions and subsequent disappearances fostered a paranoid atmosphere among parents that was ripe for conspiratorial thinking.

As the RATTA rally drew to a close, I lingered among a cluster of demonstrators at the foot of the theater stairs. Withdrawn now from the television cameras, in the intimate company of fellow kin to foreign combatants, they discreetly exchanged details of their disappearance stories:

Woman: To tell the truth, the day he left his eyes were totally green. I asked him: are you high? He said, of course not! Can I attend the mosque when I'm high? I swear to God his eyes were green. 
Man: The day he left we had a fight. My son was never violent like thathe used to respect me! He would come to me saying: father, kiss me. How could this happen to someone who always sought his father's kiss? Woman: My son never used to lie, but he started lying to me at that time. It was like he was playing the same record that they plant into everyone else.

The man speaking here was Faisal, an older father in his late sixties from the Tunis suburb of Radès. Though courteous, Faisal spoke with an undercurrent of anger that could be unsettling, particularly when we discussed his son Muhammad. Whereas the other RATTA parents often engaged in complex rationalizations to shield their sons from guilt, Faisal stood out for his candor about Muhammad's radicalization. At the time of my fieldwork, Muhammad was working as a security guard in a stable district of the Islamic State. He had regular access to Skype and frequently called home to his family in Tunisia.

According to Faisal, Muhammad had been "normal" before his religious turn. In fact, he was supernormal, possessing talent and good looks that made him a model of heteronormative masculinity. A professional athlete on the second-tier team of a popular Tunisian soccer club, Muhammad's odyssey into Salafism began after a work stint in Libya. Faisal described Salafism as a contagion that Muhammad had contracted abroad. He complained that his son had been brainwashed, behaving as if under the influence of a powerful drug.

The literature on Islamic revival abounds with narratives of generational struggle, where religion becomes the grounds for rebellion against parental authority (Khosrokhavar 1997; Rozario 2011; Fadil 2017). Yet for Tunisian youth, any desire for rebellion in the religious domain must be situated in the context of modernity's institutional erosion. Pervasive conditions of economic precarity have progressively gutted middle-class securities, undermining the prestige of social figures associated with postcolonial modernity, such as the teacher or civil servant (Meddeb 2012). Reliable mechanisms of social mobility have broken down for the younger generation, as evidenced by the swollen ranks of unemployed university graduates (diplômés chômeurs). These crisis symptoms have contributed to the unmooring of subjectivity among Tunisian youth, who no longer feel they have any purchase on the good life modernity promised (Mbembe and Roitman 1995; Piot 2010).

While Faisal understood Muhammad's religious conversion as a crisis of filial piety, he located the problem outside the home, blaming authority figures for 
failing to enmesh his son in proper relations of care. As a retired public-school teacher, Faisal strongly identified with the normative ideal of Tunisianité. He lamented the degradation of the school system as a key institution for the reproduction of national subjects: "These days there are even teachers who say bad words (kalām zāyid) in front of the students. How is that possible?" Faisal's son never thrived in the classroom, but his talent for soccer provided an escape. Yet as a professional player, disappointment whittled away at Muhammad's love for the game. Underpaid and passed over for promotion, he told his father: "The rottenest thing I ever did was play soccer. Those who are responsible, who are supposed to be mentors, are not on the right level."

Faisal never suggested that he may have played a role in Muhammad's disappearance, yet his narrative betrayed a profound discord in the father-son relation. In Tunisian families, sons are expected to treat their fathers with respect, and as a consequence, their relationship is often formal and distant (White 2004). Faisal, however, seemed to overidentify with his son's masculinity, revealing his invasiveness through persistent comments about Muhammad's sexuality. In Tunisia today, where the Islamist/secularist debate revolves around bodily practices (Zeghal 2013), the performance of modern secular subjectivity encourages the flouting of religious directives governing bodily pleasures. ${ }^{7}$ Thus, when describing Muhammad as "modern," Faisal took pains to assure me that his son had been (hetero)sexually active. "You understand?" he emphasized with a meaningful look. "Normal. You could not say he was gay." These unsolicited comments to a foreign, female researcher suggest Faisal's interpellation by a global discourse on the monstrous sexuality of the jihadi, depicted as homosexual and hyperheterosexual at the same time (Puar and Rai 2002; Puar 2007). Such representations have only proliferated with sensationalistic media coverage of the Islamic State. Faisal mobilized sexuality to establish the truth of Muhammad's subjectivity (Foucault 1990), and yet his appeals to normalcy raised the possibility of obtrusive paternal control.

Jihadi conversion cultures in Tunisia have employed a range of disciplinary practices to produce combatant subjects. Muhammad was initiated through zamaktel, a hybrid martial art that combines physical and spiritual training (Sellami and Haj Salem 2016). ${ }^{8}$ Shortly after his return from Libya, Muhammad began attending classes outside the stadium in the affluent El Menzah suburbs, led by a martial-arts expert known simply as "the Master." Each session included a spiritual audit, where trainees were interrogated about their prayer practice and sent home if found wanting. Though unconventional, Muhammad's athletic performance 
improved under the Master's tutelage, and Faisal grew confident that his son would "make a great leap in soccer" that year. Instead, one evening Muhammad demanded his passport and quit his father's home. Connecting first with al-Qaeda encampments on Tunisia's western frontier, Muhammad crossed into Algeria on foot. He then caught a plane for Istanbul en route to the Islamic State territories in Syria.

Prior to his departure, Muhammad used his emergent pious sensibilities to challenge his father's authority on religious grounds. Whereas Faisal considers himself a devout Muslim, Muhammad made a point of competing with him in the regularity of his prayer. More troublingly, when footage of ISIS's righteous atrocities began to circulate online, Muhammad showed the videos to his father, saying: "They are better Muslims than you." Faisal countered by rebuking Muhammad's behavior as un-Islamic, citing its violation of the Prophet's enjoinment to "please one's parents" (riḍā' al-wālidayn). He supported this claim with a hadith, which stated that when a young man sought to enlist during the wars of Islamic conquest, the Prophet Muhammad would ask the prospective recruit if he had his parents' permission. If the answer was no, the Prophet refused his service, suggesting that he perform jihad on behalf of his parents ( $f_{1}$ sabīl al-wālidayn) instead - remaining with them and assuring their maintenance into old age. Faisal argued that in choosing jihad over deference to his father, Muhammad violated genealogical principles central to Islam.

Faisal tells me that he has disowned Muhammad over his affiliation with the Islamic State. The charismatic "modern” athlete whom Faisal recognizes as his son has become a distant militant whose beard stretches down to mid-chest. Yet unlike other combatants whose lives in Syria remain almost entirely unknown, Muhammad has remained in close contact with his family in Tunisia via Skype. Faisal refuses to come to the computer, leaving his wife and daughter to soothe $\mathrm{Mu}$ hammad's anxiety during late-night calls that stretch on for hours. Nevertheless, I imagine that Faisal hovers just within earshot during these conversations, since he has carefully filed away the smallest details of Muhammad's life abroad. The Islamic State has perhaps not proved the religious utopia of Muhammad's dreams; his work as a security guard is tedious and he suffers from terrible insomnia. Although he tells his family he can never return to Tunisia, Faisal hopes that Muhammad is secretly biding his time, waiting for the opportune moment to escape.

In embracing jihadism, Muhammad traces a line of flight from genealogical filiation (see Deleuze and Guattari 1987), rejecting his father's authority and 
refusing to pay him deference. Yet his phone calls home attest to his continued investment in family. While the relationship with his father has reached an impasse, female kin provide Muhammad with a lateral connection to home, one that does not require him to occupy a subaltern position. Women's kin-work thus presents Muhammad with a margin of maneuver, where he can renegotiate the terms of his relationship to family.

For Faisal, however, his commitment to Tunisianité makes it impossible to assimilate the new Muhammad into his notion of family. This is particularly so because the Tunisianité to which Faisal belongs is deeply residual, undercut by the erosion of institutions that provided its material base (Williams 1977). The Ennahda party's ascension to head Tunisia's transitional government was for Faisal an unfathomable, even personal betrayal of national ideals. He therefore imagined scenarios for confronting Ennadha with responsibility for his loss: "I'd like to show them a series of pictures," illustrating the arc of his son's development since childhood. Each image would be captioned with Muhammad's age and family name, representing patrilineal descent and an unfurling promise for the future. The final photograph, however, would portray Muhammad as he appears today: clad in military fatigues, his face obscured by a thick beard. The caption would read "your son" (îbnkum), in clear reference to statements made by Ennahda embracing the Salafists as spiritual kin. With its televisual sensibility, Faisal's fantasy reads as the uncanny double of the antiterrorism campaign — only now, Ennadha is cast as the outside danger that exposes the family to calamity. Enduring attachment to Tunisianité cannot be reconciled with love for a jihadi son. For Faisal, kin-work has therefore largely retreated into the domain of fantasy.

\section{THE MISSING SON AS A SPECTRAL PRESENCE}

In addition to explicitly political performances of kinship addressed to the state, the domain of kin-work encompasses a quieter labor of sustaining hope and waiting in the meantime. Each time they stage a public event, RATTA families orient their thoughts toward an indeterminate future when they will have been reunited with their sons (Bloch 1986; Miyazaki and Swedberg 2016). For most families, a son's departure for jihad represents a journey into obscurity, where definitive knowledge of life or death cannot be ascertained. Caring for absent kin in the face of uncertainty demands an unflagging work of remembrance, to hold the loved one present amid everyday life concerns. In the slippage between remembrance and mourning, I recognize what Lisa Stevenson $(2014,15)$ theorizes as "living mournfully," an ambivalent mode of habitation that refuses "the radical 
separation of life and death." Rather than simply metabolizing loss, mournful living permits the subject to live beside the lost object of affection, resisting the embrace of death as a welcome form of closure.

I met Thoraya at the margins of RATTA's November demonstration. Wearing a black headscarf and 'abaya, Thoraya had a calm demeanor as she recounted her son Bilal's disappearance for the press. Unlike many of the other demonstrators who hung back on the theater stairs, she betrayed no shy ambivalence about publicly airing her family tragedy. One week later, Thoraya called me up, asking when I would visit her home in Ettadhamen.

Ettadhamen is a suburb of Tunis whose name has become associated with a litany of urban troubles. On the first of many visits, Thoraya welcomed me at my taxi door with what seemed like excessive caution. Taking my hand in the winter rain, she led me through a series of dense, residential alleyways to the gate of her modest home. Through my friendship with Thoraya, I learned to recognize signs of her absent son embedded throughout the house. A pastry chef by trade, Bilal exhibited a curiosity that drove him to study all manner of crafts. His mother boasted that he picked up new skills by watching the neighbors work on home-improvement projects: "He could work with electricity, with water, he knew how to mount pipes. He could do everything, mashallah." The walls and ceiling of the sitting room were imprinted with a lively stucco pattern that Bilal had designed, presided over by his portrait stationed high above the sofa. Outside in the foyer tumbled a cascade of plants, living testimony to the green thumb that Thoraya shares with her son.

Although we went over the story many times, the motivations for Bilal's passage into Syria remain mysterious to me; his communications since the time he left Ettadhamen were too scant to provide an answer. As far as his mother knew, Bilal was never interested in Salafi youth culture. He was employed, engaged to be married, and building an apartment on the roof of his mother's house where the couple would live after the wedding. To all appearances, Bilal stood within striking distance of achieving the modest dreams of young men from his social milieu: to get married, have kids, and own an apartment.

One afternoon, Bilal came home late from Friday prayers. When Thoraya scolded him for causing her worry, he said that he wanted to leave for Libya to save up money for his wedding. Bilal had worked in Libya before, but by 2013, civil war had destabilized that country. Thoraya advised her son to be patient and continue steadily saving at home. Nevertheless, the following morning, Bilal rose early and caught a bus for the Libyan border crossing at Ras Ajdir. Ever the 
responsible son, he checked in frequently with his mother during the bus ride south, but his phone calls were cut off abruptly once he crossed into Libyan territory. After five days of silence, Bilal called home again. The message was brief, but devastating: "Mother, I'm in Syria. Please forgive me. God willing, I'll return."

Some common themes recur in almost every disappearance story I collected. Perhaps the most salient is the anguished dialogue of remote communications, in which a mobile phone becomes the final thread tying a family to its missing son. During rare phone calls, the family scrutinizes each detail, such as tone of voice or long pauses or sighs, attempting to discern a hidden transcript of motivations, emotional state, and well-being. That these communications are punctuated by long periods of silence, each one haunted by the possibility that it may now last forever, enhances the value of every phone call as a source of precious information. Most families could tell me the number of days between one phone call and the next, or how much money they spent in phone credit to be reconnected when a call was dropped.

Bilal's subsequent communications revealed that he was descending ever deeper into the Syrian conflict. One evening, he told his mother that he was going on a training mission and had to relinquish his phone for security reasons. Whereas in earlier conversations Bilal had appeared to speak at ease, that day Thoraya sensed that her son was constrained - perhaps he was under surveillance and could not reveal much information? She spent the next two days heartsick, without means to verify his safety. On the third day, her daughter received a brief phone call from Syria, delivering the news that Bilal had died a martyr.

\section{AMBIGUITIES OF REMEMBRANCE}

Jihadi proselytizing in Tunis has been concentrated in the urban peripheries. These neighborhoods were settled by rural migrants in the 1970s, drawn by employment in the expanding food-processing and textile-manufacturing sectors (Sellami and Haj Salem 2016). High unemployment, social marginalization, and uneasy relations with the police have rendered these areas receptive to Salafi messaging (Lamloum and Ben Zina 2015). At the time of Bilal's departure in 2013, Ettadhamen hosted a thriving Salafi counterpublic. Although security crackdowns had sent recruitment networks underground prior to my first visit, Thoraya told me that neighborhood youth once openly encouraged each other to depart for Syria. When news of a martyrdom reached Ettadhamen, some families celebrated the occasion: "They bring a sheikh to lecture about jihad and praise the 
loudspeaker. They offer dinner to people in the street - it's just like a wedding." Local youth communicated with the militias in Syria via social media and were fluent in the codes that govern announcements of martyrdom online. Typically, a photograph of the body is posted to Facebook to establish the cause of death, while a passport or ID card confirms the martyr's identity.

Bilal's death, however, left no digital trace. His friends exchanged conflicting stories about Bilal's demise: one claimed that he had been crushed in an aerial bombardment, while another held that a sniper had shot him while he performed his prayers. The absence of documentary evidence left a wedge of doubt in Thoraya's mind, and she adamantly refuses to accept that Bilal has died. Nevertheless, on the day that she heard the news, Thoraya went into mourning by donning the black headscarf and 'abaya. She also stopped sleeping in the interior quarters of her home, laying out a foam mattress in the foyer and thus exposing herself to the winter cold. In this intermediary space of the threshold, Thoraya keeps a nightly vigil, holding herself ready to welcome Bilal on the day that he returns.

Thoraya's contradictory reaction to the news of Bilal's death illuminates the liminal position in which kin-work places the families of foreign combatants. In his analysis of rites of passage, Victor Turner (1967) describes liminality as a position of transit from one well-defined social role to another. Having "a physical but not social 'reality'” (Turner 1967, 98), the neophyte's existence is fraught with contradiction and ambiguity. In donning the black of mourning, Thoraya marks a change of social state and recognizes loss - if not as death exactly, then at least as a disappearance. But if this mode of remembrance occupies a space of transit, it is potentially endless, lacking any well-defined terminus. Moreover, as a visible sign of mourning, Thoraya's sartorial practices have estranged her from certain neighbors in Ettadhamen, members of a counterpublic for whom Bilal's death marks a martyrdom worthy of celebration. These neighbors ridicule Thoraya for her stubborn insistence that Bilal is still alive (while their sons are dead), just as they resent her activism and eagerness to court the media with Bilal's story. Thoraya maintains a distant and uneasy acquaintance with such neighbors, preferring to greet them from afar and otherwise keep to herself.

I visited Thoraya frequently during the fasting month of Ramadan. As she prepared the copious Iftar meal, the house was warmly animated by visits from her two daughters, who lived nearby with their families. A third daughter, Lobna, had moved back in following a divorce, and her sunny six-year-old son shuttled between the house and the alley where he played with friends. One evening, just before Iftar, silence fell on the dining room as we waited for sundown. Suddenly, 
Thoraya broke out in gentle sobs where she sat at the table. Lobna wandered out from the kitchen and wrapped her mother in an embrace; wiping tears from her face, she gently scolded: "Come on now_cut it out!" Smiling weakly, Thoraya said: "If Bilal were here now, the house would not be so silent. He was always coming and going, which made the house feel so lively and animated." It was Thoraya's second Ramadan without her son.

Although phone contact with Syria has fallen silent for now, Thoraya tells me that Bilal continues to send her messages, signs of both life and his persistent attachment to family. The night she heard the news of his death, as she slept outside in the foyer, Thoraya received the first of several visits from her son in a dream. It is the living Bilal who comes to her-he never arrives as a sign of death - and Thoraya holds fast to such dreams as proof that Bilal is still physically present in this world. Through the exchange of loving gestures, Thoraya makes use of the dream space to verify her son's bodily integrity. "He comes to me and says: Mother, hug me - and so I do," she explains. "I swear that he is fine." In the dream, Bilal kisses her hands and forehead in a gesture of love and respect.

In Islamic cosmologies, the dream space is not a purely imaginal realm animated by psychic energies from the unconscious; rather, it constitutes an intermediary space "between the spiritual and the material, between the visible and the invisible, between God and humans" (Mittermaier 2007, 231). Known as "the isthmus" (barzakh), the zone in which dreams unfold mediates between multiple worlds of which the natural world is but one, allowing for contact and knowledge exchange between living persons and unseen entities, including spirits of the living and the dead (el-Aswad 2010; Schielke 2012). Unlike the Freudian paradigm, in which the son's appearance would be interpreted as the nocturnal fulfillment of his mother's wish, popular Muslim understandings of the dream permit contact between mother and son, and the dream content may therefore be considered veridical. The dream suggests that Bilal is not dead, but merely occluded, absent for an undetermined interval from the time-space of Ettadhamen, but not without hope of return.

Dreams are not the only form of message that Thoraya receives from her son. There are other ways that Bilal disrupts the fabric of ordinary life to make his presence known. "We have a tradition in Tunisia," Thoraya told me, "when something stops you short like this." She placed a hand on her chest and audibly caught her breath, making a soft grunt, like a stutter in respiration. She described this affect of being struck by the remembrance of an absent loved one amid the stream of mundane activities — like washing the dishes or looking after the kids - 
as a sign that this loved one is thinking of you. "We asked an imam about it, and he said that this message can only come from someone who is still alive-it cannot come from the dead. When this feeling comes over me, I know it is a message from Bilal that has been relayed by God." While his three sisters also attest to receiving such otherworldly messages, they maintain that "it is different for mom. She is constantly thinking about Bilal.”

According to the geographer Paul Harrison (2008), the same openness to the world that renders us vulnerable to harm is also a precondition for experiencing the vitality of life. For Thoraya, the affective labor of kin-work is not only about instilling a particular feeling in others (Hardt 1999) but also about holding herself open-remaining receptive to intensities that arrive from elsewhere and declining their raw sensations into kin-meanings. Thoraya continues to offer Bilal her care by orienting her attention toward him, even as the nature of his absence remains indeterminate. Donna Haraway $(2016,103)$ reminds us that making kin is about making persons, though "not necessarily as individuals or as humans." In the face of catastrophe, Haraway $(2016,101)$ calls our attention to the task of building refuge, assembling "myriad temporalities and spatialities" to generate a place where something can nestle and be nurtured. I find this an apt description of Thoraya's kin-work for her son. Assemblage works according to an additive logic; like the image, it "can capture uncertainty and contradiction without having to resolve it" (Stevenson 2014, 10). Gathering affects, intensities, dreams, artifacts, and other physical traces, Thoraya generates personhood for Bilal in the place of his absence. This mattering provides the basis for continuous narration, establishing an unbroken presence for Bilal in the refuge of kinship.

\section{CONCLUSION}

Political transitions are fraught with peril and possibility, as foundational aspects of national life are subject to renegotiation. Just as the Arab Spring disorganized Tunisia's national borders and security regime, so, too, was the Tunisian personality decentered, opened up to formerly outlawed religious affiliations and transnational solidarities. Caught at the confluence of these forces, the Tunisian family is asked to defend the nation's integrity by maintaining its coherence as a social unit.

In its political register, kin-work insists that this relationship be one of mutual obligation. As the guardian of family welfare, the state must uphold its commitment to shelter the intimate domain of the family, despite the ideological changes wrought by political transition (Chatterjee 1993). Even if these men's 
actions mark them as enemies of the national family, the state must still protect them as sons to make good on its moral pledge. Kin-sentiment therefore lies at the center of a political strategy to move the Tunisian state from intransigence and save the family from disintegration through transnational circuits of violence. Performing kin bonds in public, families claim humanity for their sons against an overdetermined security matrix that casts them outside of citizenship. Insisting on the integrity of the household unit as a moral good, families shore up the state's pastoral power by appealing for the recognition of kinship's intimate bonds.

In seeking assistance for its missing sons, the family finds its political efficacy in emotional performances that beseech the state for its care. Exposing their pain in public, families mobilize powerful claims of both genealogy and intimacy as "semiautonomous" (Povinelli 2002, 235) forms of attachment that are inextricably intertwined. Yet kinship exceeds any political instrumentality, imbued as it is with a "surfeit of meaning, feeling, and presence" (Lambek 2013, 255). In its intimate register, kin-work appears as an aptitude for receptivity within a potentially shameful and world-destroying situation of loss. At its most fundamental level, kin-work works as a means of maintaining personhood for the absent son, assembling disparate materials to form a shelter for his presence. Just as "it matters which stories tell stories" (Haraway 2016, 101), so this work of assemblage generates the matter from which new stories of kin can emerge. In this sense, kinwork functions as a mode of affective survival for families, as well as an organizing principle for inhabiting the difficult ground of uncertainty. Beyond even hope for return, kin-work sustains familial investments of love into combatant lives.

\section{ABSTRACT}

In this article, I examine the politics of kin-work performed by families of Tunisian foreign combatants, whose sons were recruited to jihadi militias following the 2011 Arab Spring. Here, I refer to a form of affective labor that engenders kinship relations through the performance of intentional acts. In the context of postrevolutionary Tunisia, where the state is currently embroiled in a domestic war against terror, families of foreign combatants perform such kin-work to make a moral claim on the state to assist them in repatriating their sons. In doing so, they must work against security discourses that define their sons as terrorists, thereby excising them from the rights-bearing category of the human. Nevertheless, kin-work is more than just a political strategy. I thus also attend to more intimate registers of kin-work, where it serves as a method for inhabiting uncertainty and providing care for absent kin. [kinship; care; affective labor; violence; jihad; terrorism; security; Tunisia, Arab Spring] 


\section{NOTES}

Acknowledgments The research for this article would not have been possible without the generous assistance of friends in Tunisia, many of whom will remain anonymous. In particular, I wish to thank Muhammad Iqbal Ben Rejeb and the RATTA families for sharing their stories with me, as well as Youssef Ben Ammar for putting me in contact with the organization. The article was improved by interlocutors who offered their wisdom at various stages of its development, especially Anne Allison, Ellen McLarney, Engseng Ho, Laurie McIntosh, Harris Solomon, Kamran Ali, Kaushik Ghosh, Saikat Maitra, Maysoun Sukarieh, Kathryn Mathers, Chitra Joshi, Christopher Webb, Alessandra Radicati, Laura Jaramillo, and three anonymous reviewers at Cultural Anthropology. Early drafts were shaped by conversations with Samuel Shearer, Patrick Galbraith, Stephanie Friede, and Cagri Yoltar at a dissertation writers' seminar led by Louise Meintjes at Duke University. Feedback at various workshops helped sharpen the argument, including "Futures and Ruins: A Workshop on Crisis and Possibility" at Duke University, the Youth, Democracy, and Dissent series at Duke University, and the "De-Framing the Mediterranean from the Twenty-First Century" workshop organized by Forum Transregionale Studien in Crete. I am grateful to the editorial team at Cultural Anthropology, and Dominic Boyer in particular, for their guidance and care in steering the manuscript to publication. Research was supported by the Graduate School at Duke University and the Duke University Center for International and Global Studies.

1. The public service announcement can be viewed at https://www.youtube.com/ watch? $=$ p7LAzKWtJlE.

2. Although Tunisian women have joined jihadi militias, my focus on young men reflects the data collected during my fieldwork. All the families I worked with had lost sons to jihad, not daughters.

3. With the exception of Muhammad Iqbal Ben Rejeb, RATTA's director and therefore a public figure, my informants' names have been changed to protect their anonymity.

4. In elections held in October 2011, Ennahda won a preponderance of seats in the Constituent Assembly, a body charged with rewriting the constitution, electing a president, and forming a caretaker government. Ennahda ruled with a coalition known as the Troika, which included the social democratic party Ettakatol and the populist Congress for the Republic, the party of interim President Moncef Marzouki.

5. Many of these passersby referred to violence near Jebel Chaambi in Kasserine Province. Since late 2012, this mountainous region on the Algerian border had been the scene of deadly confrontations with the 'Uqbah Ibn Nāif' Brigade, an affiliate of al-Qaeda in the Islamic Maghreb (AQIM). On July 29, 2013, militants ambushed and killed eight soldiers on patrol, three of whom were left mutilated with slashed throats, making Jebel Chaambi synonymous with terrorism at the time of my fieldwork. State security forces were the main target of terrorist violence in Tunisia until 2015, when major attacks on foreign tourists were carried out in Sousse and Bardo.

6. Jenny White's (2004) ethnography focuses on kinship relations among working-class Turkish families. While I do not wish to suggest that Muslim families around the Mediterranean conform to any particular type, the intrafamily relationships described by White ring true to my understanding of Tunisian family dynamics.

7. These might include the consumption of alcohol, opting out of the Ramadan fast, and engaging in sexual intercourse before marriage.

8. Zamaktel is a martial arts form created by the Tunisian trainer Sheikh Moncef al-Werghi. The name is formed from the Arabic words for time (zaman), place (makan), and combat (qital), which constitute the "three essential elements" (Sellami and Haj Salem 2016, 133) of its practice. 


\section{REFERENCES}

Abu-Lughod, Lila

2005 Dramas of Nationhood: The Politics of Television in Egypt. Chicago: University of Chicago Press.

Allal, Amin

2011 “'Avant on tenait le mur, maintenant on tient le quartier!': Germes d'un passage au politique de jeunes hommes des quartiers populaires lors un moment révolutionnaire à Tunis." Politique Africaine, no. 121: 53-67. https://doi.org/ $10.3917 /$ polaf. 121.0053 .

Allen, Lori A.

2009 "Martyr Bodies in the Media: Human Rights, Aesthetics, and the Politics of Immediation in the Palestinian Intifada." American Ethnologist 36, no. 1: 161-80.

Aloui, Mustafa https://doi.org/10.1111/j.1548-1425.2008.01100.x.

2012 "Kasserine and January." boundary 2 39, no. 1: 55-67. https://doi.org/ 10.1215/01903659-1506247.

Amar, Paul

2011 “Middle East Masculinity Studies: Discourses of 'Men in Crisis,' Industries of Gender in Revolution." Journal of Middle East Women's Studies 7, no. 3: 36-70. https://doi.org/10.2979/jmiddeastwomstud.7.3.36.

Bayat, Asef

2015 "Plebeians of the Arab Spring." Current Anthropology 56, no. S11: S33-43. https://doi.org/10.1086/681523.

Ben Ammar, Youssef, dir.

2014 Condemné à l'espoir. Tunis: École des arts et du cinéma.

Bloch, Ernst

1986 The Principle of Hope. 3 volumes. Translated by Neville Plaice, Stephen Plaice, and Paul Knight. Cambridge, Mass.: MIT Press. Originally published in 1954 1959.

Butler, Judith

2004 Precarious Life: The Powers of Mourning and Violence. New York: Verso.

2009 Frames of War: When is Life Grievable? New York: Verso.

Carsten, Janet

2004 After Kinship. New York: Cambridge University Press.

Cavatorta, Francesco, and Fabio Merone

2015 "Post-Islamism, Ideological Evolution, and 'La Tunisianité' of the Tunisian Islamist party al-Nahda.” Journal of Political Ideologies 20, no. 1: 27-42. https://doi.org/ 10.1080/13569317.2015.991508.

Charrad, Mounira M.

2001 States and Women's Rights: The Making of Postcolonial Tunisia, Algeria, and Morocco. Berkeley: University of California Press.

Chatterjee, Partha

1993 The Nation and its Fragments: Colonial and Postcolonial Histories. Princeton, N.J.: Princeton University Press.

2004 The Politics of the Governed: Reflections on Popular Politics in Most of the World. New York: Columbia University Press.

Deleuze, Gilles, and Félix Guattari

1987 A Thousand Plateaus: Capitalism and Schizophrenia. Translated by Brian Massumi. Minneapolis: University of Minnesota Press. Originally published in 1980.

Devji, Faisal

2008 The Terrorist in Search of Humanity: Militant Islam and Global Politics. New York: Columbia University Press.

di Leonardo, Micaela

1987 "The Female World of Cards and Holidays: Women, Families, and the Work of Kinship.” Signs 12, no. 3: 440-53. https://doi.org/10.1086/494338. 
el-Aswad, el-Sayed

2010 "Dreams and the Construction of Reality: Symbolic Transformations of the Seen and the Unseen in the Egyptian Imagination." Anthropos 105, no. 2: 441-53.

Fadil, Nadia https://www.jstor.org/stable/25734814.

2017 "Recalling the 'Islam of the Parents': Liberal and Secular Muslims Redefining the Contours of Religious Authenticity." Identities 24, no. 1: 82-99. https:// doi.org/10.1080/1070289X.2015.1091318.

Franklin, Sarah, and Susan McKinnon, eds.

2001 Relative Values: Reconfiguring Kinship Studies. Durham, N.C.: Duke University Press.

Foucault, Michel

1990 The History of Sexuality, Volume 1: An Introduction. Translated by Robert Hurley. New York: Vintage. Originally published in 1976.

Handler, Richard

1988 Nationalism and the Politics of Culture in Quebec. Madison: University of Wisconsin Press.

Haraway, Donna J.

2016 Staying with the Trouble: Making Kin in the Chthulucene. Durham, N.C.: Duke University Press.

Hardt, Michael

1999 “Affective Labor.” boundary 2 26, no. 2: 89-100. https://www.jstor.org/ stable/303793.

Harrison, Paul

2008 "Corporeal Remains: Vulnerability, Proximity, and Living On after the End of the World.” Environment and Planning A 40, no. 2: 423-45. https://doi.org/ $10.1068 / \mathrm{a} 391$.

Herzfeld, Michael

1993 The Social Production of Indifference: Exploring the Symbolic Roots of Western Bureaucracy. Chicago: University of Chicago Press.

Hibou, Béatrice

2011 The Force of Obedience: The Political Economy of Repression in Tunisia. Translated by Andrew Brown. Malden, Mass.: Polity Press. Originally published in 2006.

International Crisis Group

2013 “Tunisia: Violence and the Salafi Challenge.” Middle East/North Africa Report, no. 137. https://www.crisisgroup.org/middle-east-north-africa/north-africa/tunisia/ tunisia-violence-and-salafi-challenge.

Jayal, Niraja Gopal

2013 Citizenship and its Discontents: An Indian History. Cambridge, Mass.: Harvard University Press.

Khosrokhavar, Farhad

1997 L'Islam des jeunes. Paris: Flammarion.

Lambek, Michael

2013 "Kinship, Modernity, and the Immodern." In Vital Relations: Modernity and the Persistent Life of Kinship, edited by Susan McKinnon and Fenella Cannell, 24160. Santa Fe: School for Advanced Research Press.

Lamloum, Olfa, and Mohamed Ali Ben Zina

2015 Les jeunes de Douar Hicher et d'Ettadhamen. Tunis: Arabesque.

Malkki, Liisa $\mathrm{H}$.

1996 "Speechless Emissaries: Refugees, Humanitarianism, and Dehistoricization." Cultural Anthropology 11, no. 3: 377-404. https://doi.org/10.1525/can.1996. 11.3.02a00050.

Mankekar, Purnima

1999 Screening Culture, Viewing Politics: An Ethnography of Television, Womanhood, and Nation in Postcolonial India. Durham, N.C.: Duke University Press. 
Marks, Monica

2013 "Youth Politics and Tunisian Salafism: Understanding the Jihadi Current." Mediterranean Politics 18, no. 1: 104-111. https://doi.org/10.1080/ 13629395.2013 .764657

Mbembe, Achille, and Janet Roitman

1995 "Figures of the Subject in Times of Crisis." Public Culture 7, no. 2: 323-52. https: / / doi.org/10.1215/08992363-7-2-323.

Meddeb, Hamza

2012 "Courir ou mourir: Course à el khobza et domination au quotidien dans la Tunisie de Ben Ali.” PhD dissertation, Institut d'Études Politiques de Paris. http: / /www.theses.fr/2012IEPP0030.

Meijer, Roel

2009 "Introduction." In Global Salafism: Islam's New Religious Movement, edited by Roel Meijer, 1-32. New York: Columbia University Press.

Mittermaier, Amira

2007 “The Book of Visions: Dreams, Poetry, and Prophecy in Contemporary Egypt." International Journal of Middle East Studies 39, no. 2: 229-47. https://doi.org/ 10.1017/S0020743807070080.

Miyazaki, Hirokazu, and Richard Swedberg, eds.

2016 The Economy of Hope. Philadelphia: University of Pennsylvania Press.

Piot, Charles

2010 Nostalgia for the Future: West Africa after the Cold War. Chicago: University of Chicago Press.

Povinelli, Elizabeth A.

2002 "Notes on Gridlock: Genealogy, Intimacy, Sexuality." Public Culture 14, no. 1: 215-38. https://doi.org/10.1215/08992363-14-1-215.

Puar, Jasbir K.

2007 Terrorist Assemblages: Homonationalism in Queer Times. Durham, N.C.: Duke University Press.

Puar, Jasbir K., and Amit S. Rai

2002 "Monster, Terrorist, Fag: The War on Terrorism and the Production of Docile Patriots." Social Text 20, no. 3:117-48. https://doi.org/10.1215/0164247220-3_72-117.

Roy, Olivier

2017 Jihad and Death: The Global Appeal of Islamic State. New York: Oxford Univerity Press.

Rozario, Santi

2011 "Islamic Piety against the Family: From 'Traditional' to 'Pure' Islam." Contemporary Islam 5, no. 3: 285-308. https://doi.org/10.1007/s11562-0110166-7.

Schielke, Samuli

2012 The Perils of Joy: Contesting Mulid Festivals in Contemporary Egypt. Syracuse, N.Y.: Syracuse University Press.

Schneider, David M.

1980 American Kinship: A Cultural Account. 2nd edition. Chicago: University of Chicago Press.

Sellami, Meyrem, and Jihed Haj Salem

2016 "Conversion jihadiste des jeunes en Tunisie postrevolutionaire." In Jeunes et djihadisme: les conversions interdites, 115-61. Quebec City: Presses de l'Université Laval.

Stevenson, Lisa

2014 Life Beside Itself: Imagining Care in the Canadian Arctic. Oakland: University of California Press. 
Strathern, Marilyn

1992 After Nature: English Kinship in the Late Twentieth Century. New York: Cambridge University Press.

Taylor, Diana

1997 Disappearing Acts: Spectacles of Gender and Nationalism in Argentina's "Dirty War." Durham, N.C.: Duke University Press.

Turner, Victor W.

1967 The Forest of Symbols: Aspects of Ndembu Ritual. Ithaca, N.Y.: Cornell University Press.

Weston, Kath

1991 Families We Choose: Lesbians, Gays, Kinship. New York: Columbia University Press.

White, Jenny B.

2004 Money Makes Us Relatives: Women's Labor in Urban Turkey. New York: Routledge.

Wiktorowicz, Quintan

2005 "The Salafi Movement: Violence and the Fragmentation of Community." In Muslim Networks from Hajj to Hip Hop, edited by miriam cooke and Bruce B.

Williams, Raymond

Lawrence, 208-234. Chapel Hill: University of North Carolina Press.

1977 Marxism and Literature. New York: Oxford University Press.

Zeghal, Malika

2013 "Competing Ways of Life: Islamism, Secularism, and Public Order in the

Tunisian Transition.” Constellations 20, no. 2: 254-74. https://doi.org/10. $1111 /$ cons. 12038 .

Zemni, Sami

2016 "From Revolution to Tunisianité: Who is the Tunisian People? Creating Hegemony through Compromise." Middle East Law and Governance 8, nos. 2-3: 131-50. https://doi.org/10.1163/18763375-00802002. 